Research Paper

\title{
Chemical composition of essential oil from ripe fruit of Schinus terebinthifolius Raddi and evaluation of its activity against wild strains of hospital origin
}

\author{
E.R. Cole ${ }^{1,2}$, R.B. dos Santos ${ }^{1}$, V. Lacerda Júnior ${ }^{1}$, J.D.L. Martins ${ }^{2}$, S.J. Greco ${ }^{1}$, \\ A. Cunha Neto ${ }^{1}$ \\ ${ }^{1}$ Departamento de Química, Universidade Federal do Espírito Santo, Vitória, ES, Brazil. \\ ${ }^{2}$ Departamento de Farmácia, Universidade Vila Velha, Vila Velha, ES, Brazil.
}

Submitted: August 11, 2013; Approved: March 14, 2014.

\begin{abstract}
The essential oil (EO) composition of ripe fruit of S. terebinthifolius Raddi was analyzed by GC-MS. The oil extraction yielded $6.54 \pm 1.06 \%(\mathrm{w} / \mathrm{w})$. Seventeen compounds were identified, accounting for $91.15 \%$ of the total oil, where monoterpenes constituted the main chemical class $(85.81 \%)$, followed by sesquiterpenes (5.34\%). The major monoterpene identified was $\delta$-3-carene (30.37\%), followed by limonene (17.44\%), $\alpha$-phellandrene (12.60\%) and $\alpha$-pinene (12.59\%). Trans-caryophyllene (1.77\%) was the major sesquiterpene identified. The antibacterial activity of the essential oil was evaluated against wild strains of hospital origin (Escherichia coli, Pseudomonas sp., Klebsiella oxytoca, Corynebacterium sp., Staphylococcus aureus, Enterobacter sp., Enterobacter agglomerans, Bacillus sp., Nocardia sp. and Streptococcus group D). The essential oil of the ripe fruit of S. terebinthifolius Raddi has shown to be active against all tested wild strains, with minimum inhibitory concentration ranging from $3.55 \mu \mathrm{g} / \mathrm{mL}$ to $56.86 \mu \mathrm{g} / \mathrm{mL}$. However, it has revealed some differences in susceptibility: the general, Gram-positive species showed greater sensitivity to the action of EO, which is probably due to the lower structural complexity of their cell walls.
\end{abstract}

Key words: essential oil, Schinus terebinthifolius Raddi, GC-MS, antibacterial activity.

\section{Introduction}

Currently, the problem of drug resistance in human pathogens and animals poses a serious challenge to both developed and developing countries. The consumption of more than one daily ton of antibiotics in some European countries has resulted in resistance of bacterial populations, thus causing a serious public health problem (Duarte, 2006) and becoming one of the biggest causes of failure in the treatment of infectious diseases (Hirakata et al., 1998).

The search for natural methods that are less aggressive to humans has increased considerably in recent years. Medicinal plants have been an important therapeutic resource since the dawn of time. The herbal medicine is growing, especially in recent years (Yunes et al., 2001). However, despite the increase of studies in this area, available data show that only 15 to $17 \%$ of plants were studied for their medicinal potential (Turolla and Nascimento, 2006).

Schinus terebinthifolius Raddi, popularly known as mastic, mastic red-pepper, pepper tree, Brazilian pepper or Christmas Berry, from the family Anacardiaceae, is a species originated in South America, mainly from Brazil, Paraguay, and Argentina. In Brazil, it is found from Ceará (northeast) to Rio Grande do Sul (south) (Jones, 1997).

Its bark has action against fever, hemoptysis and uterine disorders in general. Bark extract and oil are used against tumors and corneal diseases (Degáspari et al., 2004; Moustafa et al., 2007). The fruit and their essential oil (EO) are assigned antimicrobial activity on Gram-positive and anti-inflammatory by inhibiting the enzyme phospholipase $\mathrm{A}_{2}$ (Pires et al., 2004).

The species has been studied in relation to chemical composition and biological activities, because of its medic-

Send correspondence to R.B. dos Santos. Department of Chemistry, Federal University of Espírito Santo, Fernando Ferrari Avenue 514, 29.075-910 Vitória, ES, Brazil. E-mail: reginaldo.santos@ufes.br. 
inal and phytochemical (Lenzi and Orth, 2004a; Lenzi and Orth, 2004b) potential. Essential oils are volatile substances that usually have pleasant odors and are found in virtually all living tissue of plants and usually extracted by hydrodistillation (Isman, 2000). These oils play an important role in protecting against microorganisms and are bound to plant survival due to their different functions. Studies estimate that approximately $60 \%$ of EO have antifungal activity and 35\% have antibacterial activity (Lima et al., 2006a), and they are active against viruses and protozoa (Cowan, 1999).

EO consists of a mixture of hydrocarbons (terpenes) and oxygenates derived from an isoprenic unit, which in turn originates from mevalonic acid, or phenylpropanoids, stemming from shikimic acid (Cowan, 1999; Guenther, 1977; Rates, 2001).

The EO extracted from ripe fruit of S. terebinthifolius provides a predominantly monoterpenic composition (Malik et al., 1994; Pieribattesti et al., 1981).

Based on these considerations, this paper aims to characterize chemically and physicochemically the EO extracted from fruits of $S$. terebinthifolius Raddi, from the State of Espírito Santo, and evaluate its antibacterial activity against wild strains of hospital origin.

\section{Material and Methods}

\section{Plant material}

Ripe fruit from S. terebinthifolius Raddi were collected on the campus of Federal University of Espírito Santo (UFES), Goiabeiras, Vitória, Espírito Santo, Brazil (S 20¹6.8696', W 040¹8.1194').

Plant origin was identified by Solange Zanotti Schneider from the Biology Department of Vila Velha University (UVV-ES). A voucher specimen was deposited at the Herbarium of UFES (VIES 14711).

The material was subjected to drying in open air for a week at room temperature, so that there was no loss of volatile components. Subsequently, the fruits were peeled and subjected to extraction by hydrodistillation.

\section{Bacterial strains}

The bacterial cultures used in the tests were provided by a public hospital in the metropolitan region. Gramnegative bacteria: Escherichia coli; Klebsiella oxytoca; Pseudomonas sp.; Enterobacter sp.; Enterobacter agglomerans and Gram-positive bacteria: Streptococcus group D; Staphylococcus aureus; Corynebacterium sp.; Bacillus sp. and Nocardia sp.

\section{Extraction of essential oil}

The EO was extracted by hydrodistillation method using modified Clevenger apparatus coupled to a round bottom flask of $3000 \mathrm{~mL}$.
Ripe fruit of S. terebinthifolius (200 g) were peeled and ground in a blender to achieve uniform particle size, and along with $1500 \mathrm{~mL}$ of deionized water were extracted for $6 \mathrm{~h}$ counted from the start of reflux.

The hidrolact obtained was partitioned with three portions of $30 \mathrm{~mL}$ dichloromethane in a separatory funnel, and dried with anhydrous sodium sulfate, and then filtered and the solvent removed under reduced pressure $(40 \mathrm{~mm} \mathrm{Hg})$. The EO obtained was weighed and stored in amber bottle in the refrigerator. The yield of the extraction procedure was determined in triplicate.

\section{Gas chromatography with mass spectrometry (GC-MS)}

The EO was then analyzed by GC-MS using a Shimadzu QP-5000 mass spectrophotometer equipped with fused silica DB-5 [30 m x $0.25 \mathrm{~mm}$ (inside diameter), $0.25 \mu \mathrm{m}$ film thickness], using helium as carrier gas at a split ratio of 20:1. The injector and ion detector temperatures were set at $220^{\circ} \mathrm{C}$ and $230{ }^{\circ} \mathrm{C}$, respectively. The furnace temperature was programmed from $60^{\circ} \mathrm{C}$ to $240{ }^{\circ} \mathrm{C}$ at $3{ }^{\circ} \mathrm{C} / \mathrm{min}$. The mass spectra were scanned in the range of $40 \mathrm{~m} / \mathrm{z}-450 \mathrm{~m} / \mathrm{z}$. Different constituents were identified on the basis of: a) Computer matching of mass spectra with NIST library (Nist 62 MS Library); b) Comparison of their retention indices relative to homologous series of $n$-alkanes $\left(\mathrm{C}_{9}-\mathrm{C}_{24}\right)$ (Adams, 2001).

\section{Specific density}

This parameter was determined through digital densimeter (Anton Paar, model Stabinger number SVM 3000), calibrated at $20^{\circ} \mathrm{C}$, in compliance with the ASTM D5002 standard methodology (ASTM, 1999).

\section{Refractive index}

This determination was made through Abbe refractometer (Carl-Zeiss Jena, Model G), at $20{ }^{\circ} \mathrm{C}$, in compliance with the AOAC methodology (AOAC, 1995).

\section{Optical rotation}

Measurements of optical rotation of the EO, undiluted, were performed in digital polarimeter (Perkin Elmer-Polarimeter 241) that uses sodium D ray $(\lambda=$ $589.3 \mathrm{~nm}$ ) with optical path of $1 \mathrm{dm}$ and a bucket with a $0.8 \mathrm{~mL}$ capacity, at $23.5^{\circ} \mathrm{C}$.

\section{Evaluation of antibacterial activity}

\section{Sample preparation}

The EO of S. terebinthifolius Raddi was initially diluted in dimethylsulfoxide (DMSO) in order to obtain a stock solution concentration of $454.85 \mu \mathrm{g} / \mathrm{mL}$. Intermediate concentrations were prepared by diluting the stock solution in an appropriate medium so as to result in final 
concentrations $227.43,113.71,56.86,28.43,14.21,7.11$, 3.55 and $1.78 \mu \mathrm{g} / \mathrm{mL}$.

Both EO and DMSO were previously sterilized using membrane filter of $0.22 \mathrm{~mm}$ in pore size.

\section{Preparation of culture medium}

We used the Micromed ${ }^{\circledR}$ nutritive broth, prepared from dehydrated medium with the addition of distilled water according to the manufacturer's recommendation. Then it underwent autoclaving process and was deposited in test tubes.

\section{Inoculum preparation}

Before the tests, the bacterial cultures were activated by subculture on Mueller-Hinton agar for $24 \mathrm{~h}$ at $37^{\circ} \mathrm{C}$. After activation, the inoculum was standardized to $10^{8}$ cells $/ \mathrm{mL}$, which consisted in preparing a bacterial suspension in sterile saline with a turbidity tube similar to Mac Farland 0.5 Scale $(0.05 \mathrm{~mL}$ barium chloride $1 \%$ and $9.95 \mathrm{~mL}$ sulfuric acid 1\%).

\section{Proof of sensitivity by broth dilution: dilution assay in tubes}

In this assay, aliquots of $100 \mu \mathrm{L}$ of each EO dilution, $940 \mu \mathrm{L}$ of culture medium and $10 \mu \mathrm{L}$ of each microbial suspension were sampled. Then the tubes were incubated at $37^{\circ} \mathrm{C}$ for $24 \mathrm{~h}$. The test was performed in triplicate, where the Minimum Inhibitory Concentration (MIC) was defined as the lowest test concentration that inhibited visible growth of the microorganism tested (turbidity of tube contents was not verified).

\section{Positive control with gentamicin}

Positive control antibiotic Gentamicin (10 $\mu \mathrm{g} / \mathrm{disk})$ was used. When impregnated in paper discs, it is diffused into the culture medium and, in case of inhibitory activity over the microorganism tested, it forms a non-growth halo around the disc impregnated. After the incubation period the plates had undergone $\left(24 \mathrm{~h}, 37^{\circ} \mathrm{C}\right)$, the inhibition zones around each disk were measured.

\section{Negative control with DMSO}

Along with MIC test, the feasibility of the microorganism was also carried out, in which an equivalent volume of DMSO was used as a negative control. To sterile tubes containing $940 \mu \mathrm{L}$ of nutrient broth were added $100 \mu \mathrm{L}$ of DMSO and $10 \mu \mathrm{L}$ of each of the microbial suspensions used. Then the tubes were incubated at $37^{\circ} \mathrm{C}$ for $24 \mathrm{~h}$. The test was performed in triplicate. Interpretation of the results was carried out by checking the turbidity of the contents of the tube.

\section{Results and Discussion}

\section{Essential oil extraction}

The essential oils showed strong odor, pungent flavor and yellow coloring.

The percentage of essential oil extracted from the ripe fruit of $S$. terebinthifolius Raddi was $6.54 \pm 1.06 \%(\mathrm{w} / \mathrm{w})$. However, this content is still below the $10.00 \%(\mathrm{w} / \mathrm{w})$ reported by Lloyd et al. (1977). The average value found is four times higher than that reported by Pieribattesti et al. (1981) - $1.50 \%$. In all these studies, it was used the same extraction protocol.

The nature and amount of essential oils produced by plant species along its development can be significantly affected by factors such as light intensity, temperature, level of nutrition and water availability (called abiotic factors) (Lima et al., 2003).

\section{Physicochemical properties of the essential oil}

The results obtained in the physicochemical and chemical characterization of the essential oil of ripe fruit of S. terebinthifolius Raddi are presented in Table 1.

The EO of S. terebinthifolius showed predominance of monoterpenes $(85.81 \%)$, presenting as major constituents $\delta$-3-carene $(30.37 \%)$, limonene $(17.44 \%)$, $\alpha$-phellandrene $(12.60 \%)$, $\alpha$-pinene $(12.59 \%)$, myrcene $(5.82 \%)$ and o-cymene $(3.46 \%)$; sesquiterpenes appeared as minor proportion $(5.34 \%)$.

This result shows a slight qualitative similarity to those reported for samples of essential oil made from the fruit of S. terebinthifolius from the USA (Lloyd et al., 1977; Pieribattesti et al., 1981) and leaves collected in India (Jamal and Agusta, 2001; Singh et al., 1998). Ibrahim et al. (2004) in their study on the fruits of the plant detected monoterpenes $\alpha$-pinene (15.01\%) and germacrene D $(14.31 \%)$ and sesquiterpene elixene $(15.18 \%)$ as major constituents of the EO. Pieribattesti et al. (1981) obtained $\alpha$-pinene (26.50\%), $\alpha$-phellandrene $(22.30 \%)$, limonene $(16.00 \%)$ and $\beta$-phellandrene $(15.00 \%)$ as the monoterpenic predominant species. In the study carried out by Barbosa et al. (2007) on the analysis of the variation in volatile composition of the EO from the fruits of $S$. terebinthifolius vs. time of extraction, three of the four main chemical constituents obtained after one hour of extraction were identified as: $\alpha$-pinene $(6.48 \%)$, $\alpha$-phellandrene $(7.45 \%)$ and $\delta$-3-carene $(17.15 \%)$. Nascimento et al. (2011), in their work with the EO of ripe fruit of Schinus, obtained limonene (31.8\%), thujene (21.7\%), sabinene (15.8\%) and $\alpha$-phellandrene (11.9\%) as major compounds.

Table 2 shows the chemical composition of the essential oils from different parts of the plant S. terebinthifolius Raddi collected in different regions of the world. When comparing the chemical composition of the EO from fruits 
Table 1 - Physicochemical Properties and chemical composition of EO of ripe fruit of $S$. terebinthifolius Raddi.

\begin{tabular}{|c|c|c|c|c|}
\hline \multirow[t]{2}{*}{ Compound } & \multirow[t]{2}{*}{ Retention index (min.) } & \multicolumn{2}{|c|}{ Kovats Index } & \multirow[t]{2}{*}{ Peak area (\%) } \\
\hline & & Obtained & Theoretical * & \\
\hline$\alpha$-pinene ${ }^{1}$ & 4.870 & 930 & 939 & 12.59 \\
\hline sabinene ${ }^{1}$ & 5.806 & 968 & 976 & 0.61 \\
\hline$\beta$-pinene ${ }^{1}$ & 5.905 & 972 & 980 & 0.69 \\
\hline myrcene $^{1}$ & 6.279 & 987 & 991 & 5.82 \\
\hline$\alpha$-phellandrene ${ }^{1}$ & 6.697 & 1002 & 1005 & 12.60 \\
\hline$\delta$-3-carene ${ }^{1}$ & 6.922 & 1009 & 1011 & 30.37 \\
\hline o-cymene ${ }^{1}$ & 7.256 & 1019 & 1022 & 3.46 \\
\hline limonene $^{1}$ & 7.470 & 1025 & 1031 & 17.44 \\
\hline isoterpinolene $^{1}$ & 9.457 & 1084 & 1086 & 1.02 \\
\hline borneole $^{1}$ & 12.546 & 1162 & 1165 & 0.34 \\
\hline 4-terpineol ${ }^{1}$ & 12.841 & 1169 & 1177 & 0.57 \\
\hline carvacrol $^{1}$ & 18.133 & 1295 & 1298 & 0.30 \\
\hline trans-caryophyllene $^{2}$ & 23.182 & 1413 & 1418 & 1.77 \\
\hline$\gamma$-muurulene ${ }^{2}$ & 25.730 & 1474 & 1480 & 1.29 \\
\hline$E, E$ - $\alpha$-farnesene $e^{2}$ & 26.395 & 1489 & 1508 & 0.36 \\
\hline$\delta$-cadinene ${ }^{2}$ & 27.508 & 1517 & 1524 & 1.32 \\
\hline epi- $\alpha$-cadinol ${ }^{2}$ & 32.062 & 1634 & 1640 & 0.60 \\
\hline Total identified & - & - & - & 91.15 \\
\hline Physicochemical Properties & \multicolumn{4}{|c|}{ Values $^{\mathrm{a}}$} \\
\hline Specific Density $\left(\mathrm{g} / \mathrm{cm}^{3}\right)$ at $20{ }^{\circ} \mathrm{C}$ & \multicolumn{4}{|c|}{$0.9097 \pm 0.0200(\mathrm{CV}=2.2000 \%)$} \\
\hline Refractive Index at $20^{\circ} \mathrm{C}$ & \multicolumn{4}{|c|}{$1.4750 \pm 0.0001(\mathrm{CV}=0.0068 \%)$} \\
\hline Optical Rotation $\left({ }^{\circ}\right)$ at $23.5^{\circ} \mathrm{C}$ & \multicolumn{4}{|c|}{$+26.41 \pm 0.0200(\mathrm{CV}=0.0760 \%)$} \\
\hline
\end{tabular}

${ }^{1}$ Monoterpenes; ${ }^{2}$ Sesquiterpenes. *Adams (2001).

${ }^{a}$ Data are expressed as mean \pm standard deviation (coefficient of variation $=\%$ ) - three replications.

to the results shown in Table 1, there is significant variation in the composition and quantity of chemical constituents.

This observed variation in the chemical composition of the essential oil from fruits of $S$. terebinthifolius Raddi, using the same extraction protocol, holds a direct relationship with the environment in which the plant develops, the type of crop to which it is submitted and the part of the plant submitted to the extraction (Lima et al., 2006a).

\section{Antibacterial activity}

Assays of antibacterial activity performed by the broth dilution method showed that EO of S. terebinthifolius fruits was active against the microorganisms tested. Table 3 (data expressed as a function of MIC).

The EO showed to be particularly active against gram-positive bacteria Corynebacterium sp. $(3.55 \mu \mathrm{g} / \mathrm{mL})$, Bacillus sp. $(7.11 \mu \mathrm{g} / \mathrm{mL})$ and Nocardia sp. $(7.11 \mu \mathrm{g} / \mathrm{mL}$, whose MIC values were the lowest among the tested bacteria, while Gram-negative species Enterobacter sp.
(56.86 $\mu \mathrm{g} / \mathrm{mL})$, E. agglomerans $(28.43 \mu \mathrm{g} / \mathrm{mL})$, E. coli $(28.43 \mu \mathrm{g} / \mathrm{mL})$ and $K$. oxytoca $(28.43 \mu \mathrm{g} / \mathrm{mL})$ showed less sensitivity to oil (evidenced by the higher MIC values). The high frequency in some of these bacteria is detected in hospitals, especially E. coli, Enterobacter sp. and S. aureus (proven fact according to survey data recorded in the book of the hospital supplying the strains).

The marked differences among Gram-negative and Gram-positive bacteria are related to the structure of their cell walls: Gram-negative bacteria have more complex cell wall composed of a thin peptidoglycan layer, and an outer membrane containing lipopolysaccharides, which are responsible for an additional hydrophobic barrier. On the other hand, the cell wall of Gram-positive bacteria, even though thicker, shows predominantly one type of macromolecule (90\% peptidoglycan) (Murray et al., 2002). As showed in results section, the Gram-positive species are more sensitive to the EO, which is very likely to be ex- 
Table 2 - Compounds identified in the EO, using different plant parts collected from different regions of the world.

\begin{tabular}{|c|c|c|c|}
\hline Compounds & Plant part & Place of Collection & Reference \\
\hline $\begin{array}{l}\alpha \text {-pinene }(26.5 \%), \alpha \text {-phellandrene }(22.3 \%) \text {, limonene }(16.00 \%) \text {, carene } \\
\text { (traces) }\end{array}$ & Fruits & USA & $\begin{array}{l}\text { (Pieribattesti et } \\
\text { al., 1981) }\end{array}$ \\
\hline $\begin{array}{l}\alpha \text {-cadinol }(16.26 \%) \text {, elemole }(13.62 \%), \delta \text {-cadinene }(6.33 \%), \delta \text {-3-carene } \\
(5.82 \%) \text {, germacrene D-4-ol }(5.33 \%) \text {, epi- } \alpha \text {-cadinol }(4.56 \%), \beta \text {-phellan- } \\
\text { drene }(4.49 \%) \text {, germacrene D }(4.39 \%)\end{array}$ & Fruits & Brazil & (Barbosa et al., 2007) \\
\hline Limonene, $\delta$-3-carene, sabinene, p-cymene & Fruits & USA & (Lloyd et al., 1977) \\
\hline Elixene $(15.18 \%), \alpha$-pinene $(15.01 \%)$, germacrene D $(14.31 \%)$ & Fruits & Egypt & (Ibrahim et al., 2004) \\
\hline $\begin{array}{l}\text { cis- } \beta \text {-terpineole }(17.87 \%),(E) \text {-caryophyllene }(17.56 \%), \beta \text {-cedrene } \\
(9.76 \%) \text {, citronelal }(7.03 \%)\end{array}$ & Leaves & Egypt & $\begin{array}{l}\text { (El-Massry et } \\
\text { al., 2009) }\end{array}$ \\
\hline $\begin{array}{l}\text { 3-carene, } \alpha \text {-pinene, } \beta \text {-pinene, } \alpha \text {-phellandrene, } d \text {-limonene, sabinene, } p \text {-cy } \\
\text { mene, } \beta \text {-cymene, } \beta \text {-elemene, isocaryophyllene, } \alpha \text {-cubene, etc. }(68.63 \% \text { of } \\
\text { monoterpenes) }\end{array}$ & Leaves & India & $\begin{array}{l}\text { (Jamal and } \\
\text { Agusta, 2001) }\end{array}$ \\
\hline$\alpha$-pinene (24.4\%), limonene (11.9\%), p-cymene (14.3\%) & Leaves and inflorescences & India & (Singh et al., 1998) \\
\hline $\begin{array}{l}\alpha \text {-pinene }(43.20 \%) \text {, camphene }(0.42 \%), \beta \text {-pinene }(2.29 \%) \text {, sabinene } \\
(1.91 \%), \alpha \text {-phellandrene }(18.85 \%), 3 \text {-carene }(0.27 \%), \text { p-cymene } \\
(0.84 \%), \gamma \text {-terpinene }(0.76 \%) \text {, terpinolene }(1.07 \%), \beta \text {-caryophyllene } \\
(0.41 \%)\end{array}$ & Part unspecified & India & (Malik et al., 1994) \\
\hline $\begin{array}{l}\alpha \text {-phellandrene }(34.38 \%), \beta \text {-phellandrene }(10.61 \%), \alpha \text {-terpineol } \\
(5.60 \%), \alpha \text {-pinene }(6.49 \%), \beta \text {-pinene }(3.09 \%) \text { and p-cymene }(7.34 \%) \text {; } \\
\text { marked quantity of } \gamma \text {-cadinene }(18.04 \%)\end{array}$ & Berries & Tunisia & $\begin{array}{l}\text { (Bendaoud et } \\
\text { al., 2010) }\end{array}$ \\
\hline high percentage of sesquiterpene and monoterpene hydrocarbons & Leaves and fruits & Brazil & (Santos et al., 2009) \\
\hline $\begin{array}{l}\text { p-menth-1-en-9-ol }(8.32 \%), \beta \text {-pinene }(1.43 \%), \alpha \text {-thujene }(1.30 \%), \text { cam- } \\
\text { phene }(4.78 \%), \alpha \text {-fenchene }(8.46 \%) \text {, terpinen-4-ol acetate } \\
(0.62 \%), \text { bornyl acetate }(1.80 \%) \text {, caryophyllene }(2.19 \%) \text {, terpinen- } 4 \text {-ol } \\
(1.31 \%), \alpha \text {-terpineol }(1.38 \%), \text { germacrene-D }(7.91 \%), \delta \text {-cadinene } \\
(1.09 \%), \text { hedycaryol }(18.73 \%), \alpha \text {-gurjunene }(12.03 \%), \alpha \text {-eudesmol } \\
(9.18 \%), \beta \text {-eudesmol }(11.15 \%)\end{array}$ & Seeds & Brazil & $\begin{array}{l}\text { (Oliveira Junior et } \\
\text { al., 2013) }\end{array}$ \\
\hline $\begin{array}{l}\text { germacrene } \mathrm{D}(23.7 \%) \text {, bicyclogermacrene }(15.0 \%), \beta \text {-pinene }(9.1 \%) \text { and } \\
\beta \text {-longipinene }(8.1 \%) \text { as the main compounds }\end{array}$ & Leaves & Brazil & (Santana et al., 2012) \\
\hline $\begin{array}{l}\alpha \text {-pinene }(22.56 \%), \text { sabinene }(15.78 \%), Z \text {-salvene }(10.69 \%), \beta \text {-pinene } \\
(10.52 \%), \alpha \text {-funebrene }(8.82 \%) \text { and limonene }(5.52 \%)\end{array}$ & Fruits & Brazil & $\begin{array}{l}\text { (Carvalho et } \\
\text { al., 2013) }\end{array}$ \\
\hline $\begin{array}{l}\alpha \text {-pinene }(30.27 \%) \text {, camphene }(0.58 \%), \beta \text {-myrcene }(6.60 \%), \beta \text {-pinene } \\
(7.96 \%) \text {, myrcene }(1.63 \%), \alpha \text {-phellandrene }(9.86 \%), \alpha \text {-terpinene } \\
(0.77 \%) \text {, sabinene }(40.66 \%) \text {, trans- } \beta \text {-ocimene }(0.30 \%), \gamma \text {-terpinene } \\
(0.77 \%), 3 \text {-cyclohexen-1-ol }(0.61 \%)\end{array}$ & Fresh leaves & Zimbabwe & $\begin{array}{l}\text { (Gundidza et } \\
\text { al., 2009) }\end{array}$ \\
\hline
\end{tabular}

plained by the lower structural complexity of their cell walls.

The results obtained were consistent with the results of Lima et al. (2006b), who showed in their study on crude extracts obtained from the stem bark of S. terebinthifolius that there is great potential inhibitory effect on $S$. aureus, with MIC values below $100 \mathrm{mg} / \mathrm{mL}$.

Martinez et al. (1996) and Guerra et al. (2000) reported the capacity of the ethanol extract of leaves of $S$. terebinthifolius to inhibit the growth of S. aureus and Pseudomonas aeruginosa. Pereira et al. (2011), in their work with 3 different extracts of $S$. terebinthifolius (ethanol, n-butanol and n-hexane), against $S$. aureus, found the results $16.33 \pm 1.00 \mathrm{~mm}, 21.11 \pm 1.17 \mathrm{~mm}$ e $15.33 \pm 0.81 \mathrm{~mm}$, respectively.
Degáspari et al. (2005), tested the alcoholic and aqueous extracts obtained from fruits of $S$. terebinthifolius Raddi, checking inhibitory effect of alcoholic extract on $S$. aureus ATCC 6538 and Bacillus cereus ATCC 11778, but not over other bacterial strains tested: E. coli ATCC 25922, P. aeruginosa ATCC 10145 and Salmonella choleraesuis ATCC 10708; aqueous extract showed no inhibitory effect for any of the microorganisms tested.

The EO from the fresh leaves of S. terebinthifolius from Zimbabwe exhibited potent antibacterial activity against Yersinia enterocolitica, P. aeruginosa, E. coli, Acinetobacter calcoaceticus, Bacillus subtilis, Klebsielia pneumoniae and Bacillus subtilis with at least 58\% inhibition compared to the positive control (Gundidza et al., 2009). 
Table 3 - MIC of EO from S. terebinthifolius Raddi $(\mu \mathrm{g} / \mathrm{mL})$ in different nosocomial bacteria.

\begin{tabular}{|c|c|}
\hline Microorganism & $\operatorname{MIC}(\mu \mathrm{g} / \mathrm{mL})$ \\
\hline Enterobacter sp. ${ }^{1}$ & $56.86 \pm 0.84$ \\
\hline E. agglomerans ${ }^{1}$ & $28.43 \pm 0.46$ \\
\hline E. coli ${ }^{1}$ & $28.43 \pm 0.41$ \\
\hline K. oxytoca ${ }^{1}$ & $28.43 \pm 0.44$ \\
\hline Streptococcus grupo $\mathrm{D}^{2}$ & $14.21 \pm 0.65$ \\
\hline S. aureus ${ }^{2}$ & $14.21 \pm 0.60$ \\
\hline Pseudomonas sp. ${ }^{1}$ & $7.11 \pm 0.63$ \\
\hline Bacillus sp. $^{2}$ & $7.11 \pm 0.84$ \\
\hline Nocardia sp. $^{2}$ & $7.11 \pm 0.63$ \\
\hline Corynebacterium sp. ${ }^{2}$ & $3.55 \pm 0.44$ \\
\hline Positive control (gentamicin) & $10 \mu \mathrm{g} / \mathrm{disk}$ \\
\hline Negative control (DMSO) & - \\
\hline
\end{tabular}

${ }^{1}$ Gram-negative bacteria; ${ }^{2}$ Gram-positive bacteria.

According to Koyama et al. (1997), many components of the essential oils have the ability to disrupt or penetrate the lipid structure present in Gram-negative bacteria.

The toxic effects of monoterpenes in bacterial cell membrane results in expansion of the membrane with increased fluidity and permeability, disturbance in membrane proteins, inhibition of respiration and changes in ion transport process (Bisignano et al., 2005). However, considering that the EO is comprised of variety of chemical constituents, it is not possible to assign oil a specific mechanism of action, since each component can act at different sites in the microbial cell (Carson et al., 2002).

The monoterpenes are most likely responsible for the activities presented by EO tested, either by acting alone or acting synergistically with other constituents.

\section{Experimental evaluation of controls}

As positive control was used gentamicin, being this one aminoglycoside antibiotic of broad spectrum. The test results demonstrated susceptibility of strains Gram-positive and Gram-negative nosocomial opposite antimicrobial, therefore comparatively evaluated the efficacy of EO: gentamicin has proven bactericidal action, while the proposed test to evaluate the bacteriostatic activity EO, through MIC (Murray et al., 2002). Negative control (DMSO) showed no antibacterial activity against any of the microorganisms tested. The choice of dispersing and emulsifying agent used in the oil-water emulsion to be one of the factors observed to not cause interference with the MIC values obtained by dilution methods. At high concentrations, interference emulsifying agent in the susceptibility of bacteria to $\mathrm{EO}$ can be explained by the possible influence this has on bacterial growth and/or on the cell membrane permeability. The emulsifiers may act synergistically or antagonistically to active components of the EO. To minimize these effects, some authors have proposed the use of emulsifiers, including DMSO, at concentrations ranging from 0.5 to $20 \%$ solution in oil (Nascimento et al., 2007). However, in this study, the concentrations of DMSO used did not exceed $10 \%$.

\section{Conclusion}

The extraction process of the EO from the ripe fruit of S. terebinthifolius Raddi by hydrodistillation showed yield compatible with literature data, as well as values of specific density and refractive index. On the other hand, this did not occur for specific rotation values (this difference is due to variations in the chemical composition of the EO, which can also be related to conditions of analysis: specific rotation generally decreases linearly with increasing temperature, and varies with the concentration).

The study of antibacterial properties proved the sensitivity of all wild strains tested to EO: E. coli; Bacillus sp.; Pseudomonas sp.; K. oxytoca; Corynebacterium sp.; Nocardia sp.; S. aureus; Enterobacter sp.; E. agglomerans and Streptococcus group D. It showed, however, some differences in sensitivity profile, and Gram-positive species are more sensitive to the EO, which is very likely to be explained by the lower structural complexity of their cell walls. Traditional antibiotics act on a single cell site, and thus can develop bacterial resistance, there is then the EO as an alternative to the use of conventional antibiotics. The results open perspectives for future use in hospital settings.

\section{Acknowledgments}

The authors thank to Fundação de Amparo à Pesquisa do Estado do Espírito Santo (FAPES/FUNCITEC), Conselho Nacional de Desenvolvimento Científico e Tecnológico (CNPq) and Laboratório de Pesquisa e Desenvolvimento de Metodologias para Análise de Petróleos do Departamento de Química da UFES (LabPetro-DQUI/UFES) for financial support.

\section{References}

Adams RP (2001) Identification of essential oil components by cromatography/mass spectroscopy. Illinois, Carol Stream, Allured Publ. Corp.

AOAC (Association of Official Analytical Chemists) (1995) Official methods of analysis of the Association of Official Analytical Chemists, 16.ed.; Arlington, AOAC.

ASTM (American Society for Testing and Materials) (1999) Standard test method for density and relative density of crude oils by digital density analyzer. D5002. In: Annual Book of ASTM Standards; West Conshohocken, ASTM.

Barbosa LCA, Demuner AJ, Clemente AD, De Paula VF, Ismail FMD (2007) Seasonal variation in the composition of volatile oils from Schinus terebinthifolius Raddi. Quim Nova 30:1959-1965.

Bendaoud H, Romdhane M, Souchard JP, Cazaux S, Bouajila J (2010) Chemical composition and anticancer and antioxi- 
dant activities of Schinus molle L. and Schinus terebinthifolius Raddi berries essential oils. J Food Sci 75:466-472.

Bisignano G, Trombetta D, Castelli F, Sarpietro MG, Venuti V, Cristani M, Daniele C, Saija A, Mazzanti G (2005) Mechanisms of antibacterial action of three monoterpenes. Antimicrob Agents Chemother 49:2474-2478.

Carson CF, Mee BJ, Riley TV (2002) Mechanisms of Action of Melaleuca alternifolia (tea tree) oil on Staphylococcus aureus determined by time-kill, lysis, leakage and salt tolerance assays and electron microscopy. Antimicrob Agents Chemother 46:1914-1920.

Carvalho MG, Melo AGN, Aragão CFS, Raffin FN, Moura TFAL (2013) Schinus terebinthifolius Raddi: chemical composition, biological properties and toxicity. Rev Bras Pl Med (Botucatu) 15:158-169.

Cowan MM (1999) Plant products as antimicrobial agents. Clin Microbiol Rev 12: 564-582.

Degáspari CH, Waszczynskyj N, Prado MRM (2005) Atividade antimicrobiana de Schinus terebinthifolius Raddi. Ciênc Agrotec 29:617-622.

Degáspari CH, Waszczynskyj N, Santos RJ (2004) Atividade antioxidante de extrato de fruto de aroeira (Schinus terebinthifolius Raddi). Vis Acad 05:83-90.

Duarte MCTD (2006) Atividade Antimicrobiana de Plantas Medicinais e Aromáticas Utilizadas no Brasil. MultiCiência 07:01-16.

El-Massry KF, El-Ghorab AH, Shaaban HA, Shibamoto T (2009) Chemical compositions and antioxidant/antimicrobial activities of various samples prepared from Schinus terebinthifolius leaves cultivated in Egypt. J Agric Food Chem 57:5265-5270.

Guenther E (1977) Individual essential oils of the plant family Myrtaceae. In: The essential oils. New York, Van Nostrand. v. 4.

Guerra MJM, Barreiro ML, Rodríguez ZM, Rubalcaba Y (2000) Actividad antimicrobiana de un extracto fluido al $80 \%$ de Schinus terebinthifolius Raddi (Copal). Rev Cubana Plant Med 05:23-25.

Gundidza M, Gweru N, Magwa ML, Mmbengwa V, Samie A (2009) The chemical composition and biological activities of essential oil from the fresh leaves of Schinus terebinthifolius from Zimbabwe. Afr J Biotechnol 8:71647169.

Hirakata Y, Izumikawa K, Yamaguchi T, Takemura H, Tanaka H, Yoshida R, Matsuda J, Nakano M, Tomono K, Maesaki S, Kaku M, Yamada Y, Kamihira S, Kohno S (1998) Rapid detection and evaluation of clinical characteristics of emerging multiple-drug-resistant gram-negative rods carrying the metallo-beta-lactamase gene bla ImP. Antimicrob Agents Chemother 42:2006-2011.

Ibrahim MT, Fobbe R, Nolte J (2004) Chemical composition and biological studies of Egyptian Schinus molle L. and Schinus terebinthifolius Raddi oils. Bull Fac Pharmacy Cairo Univ 42:289.

Isman MB (2000) Plant essential oil for pest and disease management. Crop Protec 19:603-608.

Jamal Y, Agusta A (2001) Chemical composition of essential oil Schinus terebinthifolius Raddi leaves. Indonesian J Pharm 12:135-139.
Jones D (1997) Biology of Brazilian pepper. In: Chairmann, D.C. Brazilian pepper management plan for Florida. Florida, Florida Exotic Pest Plant Council.

Koyama S, Yamaguchi Y, Tanaka S, Motoyashima J (1997) A new substance (yoshixol) with an interesting antibiotic mechanism from wood oil of japanase traditional tree (kisohinoki), Chamaecyparis obtusa. Gen Pharmacol 28:797804.

Lenzi M, Orth AI (2004a) Caracterização funcional do sistema reprodutivo da aroeira vermelha (Schinus terebinthifolius Raddi), em Florianópolis-SC, Brasil. Rev Bras Frutic 26:198-201.

Lenzi M, Orth AI (2004b) Fenologia reprodutiva, morfologia e biologia floral de Schinus terebinthifolius Raddi (Anacardiaceae), em restinga da Ilha de Santa Catarina, Brasil. Biotemas 17:67-89.

Lima HRP, Kaplan MAC, Cruz AVM (2003) Influência dos fatores abióticos na produção e variabilidade de terpenóides em plantas. Flor Amb 10:71-77.

Lima IO, Oliveira RAG, Lima EO, Farias NMP, Souza EL (2006a) Atividade antifúngica de óleos essenciais sobre espécies de Candida. Rev Bras Farmacogn 16:197-201.

Lima MR, Souza LJ, Santos AF, Andrade MC, Sant'ana AE, Genet JP, Marquez B, Neuville L, Moreau N (2006b) Antibacterial activity of some Brazilian medicinal plants. J Ethnopharm 105:137-147.

Lloyd HA, Jaouni TM, Evans SL, Morton JF (1977) Terpenes of Schinus terebinthifolius. Phytochemistry 16:1301-1302.

Malik MS, Mahmud S, Sattar A (1994) Studies on the essential oil of Schinus terebenthifolius. Sci Int (Lahore) 6:351-352.

Martinez MJ, Betancourt J, Alonso-Gonzales N, Jaurequi A (1996) Screening of some Cuban medicinal plants for antimicrobial activity. J Ethnopharm 52:171-174.

Moustafa AMY, Kouam SF, Kulsoom A, Ejaz A, Ali S, Anjum S, Choudhary MI (2007) Phytochemical investigation and biological evaluation of Schinus terebinthifolius. Res J Phytochem 1:01-11.

Murray PR, Rosenthal KS, Kobayashi GS, Pfaller MA (2002) Medical Microbiology. St. Louis, Mosby.

Nascimento AF, Câmara CAG, Moraes MM, Ramos CS (2011) Essential oil composition and acaricidal activity of Schinus terebinthifolius from atlantic forest of Pernambuco, Brazil, against Tetranychus urticae. Nat Prod Commun 7:1-4.

Nascimento PFC, Nascimento AC, Rodrigues CS, Antoniolli ÂR, Santos PO, Barbosa Júnior AM, Trindade RC (2007) Atividade antimicrobiana dos óleos essenciais: uma abordagem multifatorial dos métodos. Rev Bras Farmacogn 17:108113.

Oliveira Junior LFG, Santos RB, Reis FO, Matsumoto ST, Bispo WMS, Machado LP, Oliveira, LFM (2013) Efeito fungitóxico do óleo essencial de aroeira da praia (Schinus terebinthifolius Raddi) sobre Colletotrichum gloeosporioides. Rev Bras P1 Med (Botucatu) 15:150-157.

Pereira EMR, Gomes RT, Freire NR, Aguiar EG, Brandão MGL, Santos VR (2011) In vitro antimicrobial activity of Brazilian medicinal plant extracts against pathogenic microorganisms of interest to dentistry. Planta Med 77:401-404.

Pieribattesti JC, Conan JY, Grondin J, Vincent EJ, Guerere M (1981) Contribution a létude chimique des baies roses de bourbon. Ann Falsif Expert Chim Toxicol 74:11-16. 
Pires OC, Taquemasa AVC, Akisue G, Oliveira F, Araújo CEP (2004) Análise preliminar da toxicidade aguda e dose letal mediana $\left(\mathrm{DL}_{50}\right)$ comparativa entre os frutos de Pimentado-Reino do Brasil (Schinus terebinthifolius Raddi) e Pimenta-do-Reino (Piper nigrum L.). Acta Farm Bonaer 23:176-182.

Rates SMK (2001) Plants as sources of drugs. Toxicon 39:603-613.

Santana JS, Sartorelli P, Guadagnin RC, Matsuo AL, Figueiredo CR, Soares MG, Da Silva AM, Lago JHG (2012) Essential oils from Schinus terebinthifolius leaves - chemical composition and in vitro cytotoxicity evaluation. Pharm Biol 50:1248-1253.

Santos ACAS, Rossato M, Agostini F, Serafini LA, Dos Santos PL, Molon R, Dellacassa E, Moyna P (2009) Chemical com- position of the essential oils from leaves and fruits of Schinus molle L. and Schinus terebinthifolius Raddi from Southern Brazil. J Essent Oil Bear Pl 12:16-25.

Singh AK, Singh J, Gupta KC, Brophy J (1998) Essential oil of leaves and inflorescence of Schinus terebinthifolius: an exotic plant of India. J Essent Oil Res 10:697-699.

Turolla MSR, Nascimento ES (2006) Informações toxicológicas de alguns fitoterápicos utilizados no Brasil. Rev Bras Cienc Farm 42:289-306.

Yunes R, Pedrosa RC, Cechinel Filho V (2001) Fármacos e fitoterápicos: a necessidade do desenvolvimento da indústria de fitoterápicos e fitofármacos no Brasil. Quim Nova $24: 147-152$

All the content of the journal, except where otherwise noted, is licensed under a Creative Commons License CC BY-NC. 